\title{
Ethnobotanical and Preliminary Phytochemical Screening of a Climbing Fern Lygodium flexuosum (L).S.W.
}

\author{
Anubhuti Singh \\ Assistant Professor, Department of Botany, Nirmala College, Ranchi-834002, India
}

\begin{abstract}
The present paper deals with the ethnobotanical and preliminary phytochemical screening of a beautiful climbing fern Lygodium flexuosum (L).S.W.Schrad. The decoction prepared from plant parts is used by tribal people for curing many diseases like Jaundice, liver disorder, ulcer, cough and different type of skin infections. The extraction of plant material was done by hot maceration method in solvent Ethanol. Chemical group test detect the presence of Alkaloids, Flavonoides, tannin and saponin.
\end{abstract}

Keywords: Ethnomedicinal, Phytochemical, Lygodium Flexuosum.

\section{Introduction}

Study area capital of Jharkhand is located at $23.23^{\circ} \mathrm{N}$ latitude and $85.23{ }^{\circ} \mathrm{E}$ longitude and comprises an area of 7574 sq. Km. This city is located at height of $2140 \mathrm{ft}$. above the sea level. Geographically Ranchi is located in Chhotanagpur platue. Total population of Ranchi district is 2185064. The area is dominated by tribal population. At district level, the total population of ST's is $41.82 \%$ where as SC's constitute only $5.17 \%$ of population as per 2000 census. The ethnic groups in this area are Munda, Ho, Kharia, Oraons, Bedias, Purans ,Lohra and Shanthals. Among these ethnic groups Munda and Oraoans are the dominated group in district.

The term ethnobotany is however very recent, just 110 year old, perhaps it can be called presumptuous to try to foresee or forecast its evolution in the leave aside a millennium, even a century. Ethnobotany appears to be bridge between botany and medicinal plants, but in fact it is much more. It starts a step before even botany in the sense that it supplies the idea and the basic materials for botanical research and study (Mohanka, 2006). An ethnobotany contains mainly 3 criteria floristic diversity, ethnic diversity and a rich tradition. Ranchi district of Jharkhand can fulfill all these 3 criteria.Tribes of Ranchi district are aware with the medicinal value of plants. They use different verities of plants for curing different diseases including the pteridophytes. From Ranchi 33 pteridophytes are reported among which 8 are highly medicinal. Lygodium flexuosum (L).S.W.Schrad is one of them. Lygodium belongs to schizaeaceae family having terrestrial climbing habit. The rhizome is hairy and dorsiventral. Fronds are unequally dichotomous. The sporangia may be borne singly and marginal in position, each procted by a small flap. They have arisen in close rows on pinnately arranged lobes. The plant is frequently used by tribes in liver disorders and skin infections.

\section{Materials and Methods}

Climatic conditions of the Ranchi district are favorable for the growth of pteridophytic vegetation. The pteridophytic vegetation is at its best in both variety and growth during the rainy season. The rainy season is generally followed by a short dry period with scanty rain and low temperature. They attain maturity from September- December. Successive survey work was done at the same place during SeptemberDecember which was followed by second survey during October-January.

Plants were collected with their basal portion as shape of rhizome, hairs and scales present on rhizome are important taxonomic characters. Fronds with their sori were collected. Rural and urban area of Ranchi covering all the blocks were regularly visited for gathering the information of baidya , Knowledgeble person and tribal people above themselves and the medicinal pteridophytes used by them. Questionnaire were mainly based on information regarding the family background of baidya and tribal people, plant parts used by them, time of collection, mode of diagnosis, method of preparation of drugs, curative property of plant and duration of treatment. Another questionnaire was prepared from the cured person were mainly based on information regarding- age of patient, duration of disease, type of disease and satisfied or not from the herbal medicine.

For preliminary phytochemical analysis plants were collected and dried in shade. To make powder dried plants were grinded in mixture. The powder analysis of drug was done by means of colour, odour and test evaluation of powder. Physical evaluation was done by calculating the moisture content, ash value, extractive value and $\mathrm{Rf}$ value by the method prepared by Kokate and Purohit 2003. The plant materials were extracted by the hot maceration method using the soxhlet apparatus. Extract obtained from hot maceration method were used for chemical test analysis, which detect the presence or absence of phytochemical compounds such as alkaloids, flavanoides, steroids, tannin saponin, etc. and in chromatography. The entire tests were done by the conventional methods proposed by Bhattacharjee and Das 1969.

\section{Observation}

Vernacular name- Kalijar 


\section{International Journal of Science and Research (IJSR) \\ ISSN (Online): 2319-7064}

Index Copernicus Value (2015): 78.96 | Impact Factor (2015): 6.391

Family- Schizacaceae.

Distribution- the genus is mostly tropical in distribution. A genus of climbing fern, twining around support and growing to a great height. Native of east India and Malayan Archipelayo.

Collection site- Generally found on forest area where it climbs on large trees. Collected from sita fall, johna fall, dasam fall and horab forest.

\section{Macroscopic characters}

A very beautiful climbing terrestrial fern, creeping rhizome, fronds various, sub-bipartite, fronds is in pairs on long stalks and opposite to each other. Pinnulues are about 12 inches in length, smooth and vivid green, lanceolate and serrulate. The venation is open, dichotomous where the veins are joined by marginal veins. Pinnules are narrowerand bearing the spore along the edges. Ovate or oblong-ovoid, sessile, each with a complete distal annulus, each sporangium with a separate false indusium, spores numerous.

\section{Ethnomedicinal uses}

Parts used- young shoots, whole plant, rhizome , leaves.

1) Rhizome boiled with mustard oil and applied in the treatment of sprains, carbuncle ,and eczema.

2) Rhizome is boiled with water and taken orally in case of ulcer and cough.

3) The paste of rhizome is applied in piles.

4) Juice of complete plant is used for curing fever.

5) Juice of fresh leaves is taken in case of treatment of jaundice and liver disorders.

6) The plant powder is used as expectorant.

\section{Dosage}

1) Juice of fresh leaves -half cup twice daily for 3-4 days.

2) Plant powder- $5 \mathrm{gm}$ daily with milk.

\section{Phytochemical screening}

Moisture content of plant was 3.72(table-1). Ash value was 4.74 (table-2). Extractive value was found high in solvent ethanol. So the extraction of plant material was done in solvent ethanol (table-3). Chemical group test detect the presence of alkaloids, flavonoides, tannin and saponin(table4)

\section{TLC}

The plate seen in UV chamber in long wave length showed 3 bands of pink colour. Solvent run was $9 \mathrm{~cm}$ and solute run was $2 \mathrm{~cm}$. the Rf value calculated was 0.22 (table-5)

\section{Chemical constituents}

Triterpene ester, Anthraquinone, Dryocrassol, Tectoquinone, Kaemferol, Beta-sitosterol and Stigmasterol(Singh,1999).

Table 1: Moisture content

\begin{tabular}{|c|c|c|c|c|}
\hline $\begin{array}{c}\text { No. of } \\
\text { observation }\end{array}$ & $\begin{array}{c}\text { Initial weight } \\
\text { of fresh leaf }\end{array}$ & $\begin{array}{c}\text { Final weight } \\
\text { of material } \\
\text { after drying }\end{array}$ & difference & $\begin{array}{c}\text { Moisture } \\
\text { content }\end{array}$ \\
\hline 1 & $5 \mathrm{mg}$ & $1.28 \mathrm{gm}$ & 3.72 & \multirow{2}{*}{$3.72 \%$} \\
\hline 2 & $5 \mathrm{mg}$ & $1.26 \mathrm{gm}$ & 3.74 & \multirow{2}{*}{$1.29 \mathrm{gm}$} \\
\hline 3 & $5 \mathrm{mg}$ & 3.71 & \\
\hline
\end{tabular}

Table 2: Ash value

\begin{tabular}{|c|c|c|c|c|}
\hline $\begin{array}{c}\text { No. of } \\
\text { bservation }\end{array}$ & $\begin{array}{c}\text { Initial weight } \\
\text { of material }\end{array}$ & $\begin{array}{c}\text { Final weight of } \\
\text { material after drying }\end{array}$ & difference & $\begin{array}{c}\text { Ash } \\
\text { value }\end{array}$ \\
\hline 1 & $5 \mathrm{mg}$ & $0.24 \mathrm{gm}$ & $4.76 \mathrm{gm}$ & $4.74 \%$ \\
\hline 2 & $5 \mathrm{mg}$ & $0.27 \mathrm{gm}$ & $4.73 \mathrm{gm}$ & \\
\hline 3 & $5 \mathrm{mg}$ & $0.26 \mathrm{gm}$ & $4.74 \mathrm{gm}$ & \\
\hline
\end{tabular}

Table 3: Extractive value

\begin{tabular}{|c|c|c|c|c|}
\hline Solvent & $\begin{array}{c}\text { Initial weight } \\
\text { of beaker }\end{array}$ & $\begin{array}{c}\text { Weight of } \\
\text { extract + beaker }\end{array}$ & difference & $\begin{array}{c}\text { Extractive } \\
\text { value }\end{array}$ \\
\hline Methanol & $27.36 \mathrm{gm}$ & 27.42 & $0.06 \mathrm{gm}$ & $1.2 \%$ \\
\hline Ethanol & $29.98 \mathrm{gm}$ & $30.14 \mathrm{gm}$ & $0.16 \mathrm{gm}$ & $3.2 \%$ \\
\hline benzene & $27.89 \mathrm{gm}$ & $28.02 \mathrm{gm}$ & $0.13 \mathrm{gm}$ & $2.6 \%$ \\
\hline
\end{tabular}

Table 4: Chemical group test

\begin{tabular}{|l|c|c|}
\hline Experiment & Observation & Inference \\
\hline $\begin{array}{l}\text { 1. For alkaloid } \\
3 \text { ml of extract +few drop of } \\
\text { wagner's reagent }\end{array}$ & $\begin{array}{c}\text { Orange } \\
\text { brown ppt. } \\
\text { formed }\end{array}$ & $\begin{array}{c}\text { Alkaloid } \\
\text { present }\end{array}$ \\
\hline $\begin{array}{l}\text { 2. For flavonoids } \\
\text { Extract + shulphuric acid } 10 \%, \\
\text { cooled chloroform }+1 \mathrm{ml} \text { dilute } \\
\text { sodium carbonate }\end{array}$ & $\begin{array}{c}\text { Yellow } \\
\text { colour } \\
\text { appeared }\end{array}$ & $\begin{array}{c}\text { Flavonoid } \\
\text { present }\end{array}$ \\
\hline $\begin{array}{l}\text { 3. For steroid } \\
\text { Extract + conc. H2SO4 + } \\
\text { Chloroform }\end{array}$ & $\begin{array}{c}\text { Green colour } \\
\text { appeared }\end{array}$ & $\begin{array}{c}\text { Steroid } \\
\text { absent }\end{array}$ \\
\hline $\begin{array}{l}\text { 4. For reducing sugar } \\
\text { Extract }+10 \% \text { Fehling solution } \\
\text { (1) \& (2) }\end{array}$ & $\begin{array}{c}\text { Green colour } \\
\text { appeared }\end{array}$ & $\begin{array}{c}\text { Reducing } \\
\text { sugar } \\
\text { absent }\end{array}$ \\
\hline $\begin{array}{l}\text { 5. For tannin } \\
\text { Extract + 10\% Potassium } \\
\text { dichromate }\end{array}$ & $\begin{array}{c}\text { Yellow } \\
\text { brown ppt. }\end{array}$ & $\begin{array}{c}\text { Tannin } \\
\text { present }\end{array}$ \\
\hline $\begin{array}{l}\text { 6. For saponin } \\
\text { Powdered drug is shaked with } \\
\text { water }\end{array}$ & Stable foam \\
formed & $\begin{array}{c}\text { Saponin } \\
\text { present }\end{array}$ \\
\hline
\end{tabular}

Table 5: TLC

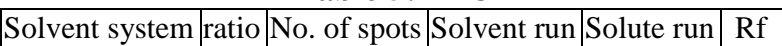

\begin{tabular}{|c|c|c|c|c|c|}
\hline Toluene:water & $98: 2$ & 2 & $9 \mathrm{~cm}$ & $2 \mathrm{~cm}$ & 0.22 \\
\hline
\end{tabular}

\section{Discussion}

Pteridophytes are considered least known and economically less important group of plant in plant kingdom. The fern and fern allies in comparison to phanerogams have received very little attention to ethnobotanist. Ethnobotanical notes on 19 taxa belonging to 12 genera and 11 family of pteridophytes of Jammu Kashmir have been reported (Kirn et. al.2001). Lygodium flexuosum exhibit antifertility activity. It contains a new compound O-P-Coumalyl-dryocrassol, tetraquinone, Karempfesol-3-B-D-glucose, B-sisosterol and stigmastesol (Achari et.al.1986). Unreported uses of less known climbing fern Lygodium flexuosum among the tribes of Bihar and Orissa is reported for ethnopteridiolodical records (Girach et.al.1989). The plant is used as expectorant and in fever, roots are used in abdominal pain(Jha et. al. 2003). The fronds of plants are used to neutralize toxic effect in animals due to consumption of poisonous leaves (Bihu S 2008). Root pounded and tablets prepared from powder, given to treat poison in body and in case of rickets (Tripathi K.P. et. al.2008). Chemical constituents of plant are triterpene ester, Kaenferol, B-sisosterol and stigmastesol.

Lygodium flexuosum (L) SW.Schrad is generally found in forest area of Ranchi district. Young shoot, rhizome and 


\section{International Journal of Science and Research (IJSR) \\ ISSN (Online): 2319-7064 \\ Index Copernicus Value (2015): 78.96 | Impact Factor (2015): 6.391}

leaves are used as medicine by tribal people. Rhizome boiled with mustard oil is applied in the treatment of sprains, carbuncle and eczema. Rhizome is boiled with water and taken orally in case of ulcer and cough. The paste of rhizome is applied in case of piles. Juice of fresh leaves is taken in case of treatment of jaundice and liver and liver disorder. The whole plant powder is used as expectorant. Chemical group test detect the present of alkaloids, flavanoids tannin and saponin.

The knowledge of fern and fern allies is not properly explored so far though a huge no. of fern and fern allies are growing in moist shady places naturally but these non flowering plants are treated as eradicable weeds due to lack of awareness. Therefore intensive work of medicinal pteridophytes plants is required with a view to enrich our knowledge of tribal folk medicines for treatment of various diseases.

\section{References}

[1] Achari, Basudeb,Basu Krishnakali, 1986. A new triterpene easter, an anthraquinone \& other constituents of the fern Lygodium flexuosum. Planta Medo (4):329330.

[2] Bhattacharjee A.K \& Das A.K, 1969. Quat J Crude drug Res.9:1408

[3] Binu S, 2008. Uses of pteridophytes among the tribals in Pathanamthitta district, Kerela. Journal of Non Timber forest product 15(2):129-131.

[4] Girach R.D \& Aminuddin, 1989. Ethnopteridological notes on Lygodium Flexuosum J. Econ Taxon Bot 13(2):255-257.isgadh, J Econ Tax Bot. 27(4):996-997.

[5] Jha , Kumar A, Suman 2003. Medicinal Pteridophytes of Baster, Chhattisgadh , J Econ Tax Bot. 27(4):996997.

[6] Kokate C.K, Purohit A.P, Gokhale S.B,2003. Pharmacognosy $22^{\text {nd }}$ edition, Nirali Praksan Pune.

[7] Mohanka 2006. Ethnomedicinal research unfolds the new vistas of traditional medicine. J .Plant Sci. 1(1) :6374.

[8] Pandey R.K, Thakur S \& Srivastava R.B.2008. Medicinal fern and fern allies of Bihar. International symposium on perspectives in pteridology Nov.27-29.

[9] Tripathi K.P, Rawat A.K.S \& Melhrotra 2008. Exploration, distribution and ethnobotanical studies on some important medicinal plants used by the tribes of Ranchi district, Jharkhand. Journal of Non - Timber forest products. 15(4):271-274.

[10] Singh H.B. 1999. Potential medicinal pteridophytes of India \& their chemical constituents. J Econ Tax Bot(1):63-78. 